\title{
A comparison of milk fatty acid profile among three different dairy production systems in Los Ríos District, Chile ${ }^{\#}$
}

\author{
Comparación del perfil de ácidos grasos de la leche entre tres sistemas distintos \\ de producción lechera en la Región de Los Ríos, Chile \\ R Morales ${ }^{\mathrm{a}^{*}}$, F Lanuza ${ }^{\mathrm{a}}$, I Subiabre ${ }^{\mathrm{a}}$, AM Carvajal ${ }^{\mathrm{a}}$, F Canto $^{\mathrm{a}}$, EM Ungerfeld \\ anstituto de Investigaciones Agropecuarias, INIA Remehue, Osorno, Chile. \\ bInstituto de Investigaciones Agropecuarias, INIA Carillanca, Temuco, Chile.
}

\begin{abstract}
RESUMEN
El objetivo de este estudio fue comparar tres sistemas distintos de producción lechera en la Región de Los Ríos, Chile, con énfasis en el perfil de ácidos grasos de la leche. Para ello se seleccionaron nueve predios representativos sobre la base de una encuesta y se clasificaron en tres sistemas de producción: pastoril (GS), mixto (MX) y ración totalmente mezclada (TMR). Muestras de leche de estanque se obtuvieron mensualmente durante 18 meses, para su posterior análisis de composición de leche y perfil de ácidos grasos. Los sistemas pastoril y mixto tuvieron la mayor concentración de ácidos grasos $n$-3 y ácido ruménico, lo que se asoció al alto consumo de pradera. Las muestras de leche de los sistemas pastoril y mixto tuvieron más del doble de ácido ruménico que la leche del sistema TMR al final del invierno y durante la primavera. Estos resultados concuerdan con estudios previos que mostraron altas concentraciones de ácidos grasos beneficiosos para la salud en leche de sistemas pastoriles.
\end{abstract}

Palabras clave: ácidos grasos, CLA, Holstein Friesian, calidad de leche.

\section{SUMMARY}

The objective of this study was to compare three different dairy production systems in Los Ríos District, Chile, with regards to milk fatty acids profile. Nine representative farms were selected from a survey and classified into three systems: grazing (GS), mixed (MX) and total mixed ration (TMR). Bulk milk tank samples were monthly obtained during an 18-months period, and milk components and fatty acid analyses were conducted. The grazing and mixed systems had higher concentrations of $n-3$ fatty acids and rumenic acid, which was associated to higher pasture intakes. Milk from grazing and mixed systems had twice as much rumenic acid than milk from TMR system in late winter and spring. These results are coincident with previous studies showing higher concentrations of fatty acids beneficial to human health in milk from grazing cows.

Key words: fatty acids, CLA, Holstein Friesian, milk quality.

\section{INTRODUCTION}

Milk fatty acid profile has an influence on human health (Lock and Bauman 2004). Rumenic acid (RA, Conjugated Linoleic Acid cis-9 trans-11-18:2) is a fatty acid present in ruminant milk fat and adipose tissues with positive attributes to human health. Rumenic acid in milk is produced during biohydrogenation of unsaturated fatty acids in the rumen and by endogenous synthesis in the mammary gland (Lock and Bauman 2004, Kalač and Samková 2010). Rumenic acid possess anticarcinogenic and immunostimulant properties among other effects (Whigham et al 2000, Albers and Wielen 2003, Haug et al 2007, Crumb 2011, Dilzer and Park 2012). Milk is also a source of n-3 fatty acids, which are claimed to prevent cardiovascular disease, type 2 diabetes, rheumatoid arthritis, asthma, and several

\footnotetext{
Accepted: 18.12.2014.

\# FONDEF-Regional Región de Los Ríos D10R1012.

*rrmorales@inia.cl
}

cancers, amog others benefitial properties (Ruxton et al 2004, Hibbeln et al 2006, DeFilippis and Sperling 2006, Haug et al 2007).

It is well documented that the diet of the animal affects the fat content and fatty acid composition of milk (Bauman and Griinari 2003, Bauman et al 2008). Milk from animals fed on pasture contains more $n-3$ fatty acids and rumenic acid than milk from animals fed grain and concentrates (Kay et al 2005, Gómez-Cortés et al 2009), due to the high content of linolenic acid $(n-3)$ in pasture fatty acids (Elgersma et al 2003, Vanhatalo et al 2007). Kelly et al (1998) and White et al (2001) reported that milk from grazing cows had double RA concentration in milk fat compared to milk from cows fed on corn-based mixed diet.

In recent years, consumers are demanding healthier food (Schnettler et al 2010, Realini et al 2014). A recent study has shown that consumers are willing to pay a premium price for products enriched with $n-3$ and/or CLA fatty acids (Realini et al 2014). In addition, Chilean consumers positively value animals fed on pasture and raised outdoors (Schnettler et al 2008, Morales et al 2013). The 
Chilean dairy sector has grown steadily in the last decades, with $77 \%$ of production taking place in the Los Ríos and Los Lagos regions (between $39^{\circ} 37^{\prime}$ ' and $44^{\circ} 3^{\prime}$ ' parallels south, ODEPA 2014). The majority of dairy production in the Los Ríos and Los Lagos regions relies on grazing of temperate pastures. Pasture production varies amply throughout the year, with low growth rates in winter and dry summers (Balocchi 1986). To face pasture deficits, conserved forage and grain are supplemented in winter, and forage crops such as fodder turnips (Brassica rapa) or raps (Brassica napus) are used in summer.

Milk produced in pasture-based Chilean systems may have a healthier fatty acids profile and potentially add value to Chilean dairy products. However, there is limited scientific information about the influence of different Chilean production systems on milk fatty acid profile. The objective of this study was to evaluate the fatty acids profile of milk produced in the Los Ríos region of Chile under three different dairy production systems.

\section{MATERIAL AND METHODS}

\section{FARM SELECTION}

Nine farms were selected out of a total of 90 farms surveyed. Farms were classified into three feeding systems, with three farms per system: grazing (GS), mixed (MX), and total mixed ration (TMR). Criteria to select the farms and main characteristics of each system are shown in the table 1 .

\section{SAMPLING AND RECORDS}

Milk production of each farm was recorded daily during the study period (18 months). Each farm was visited monthly between April 2012 and September 2013, and bulk-tank milk samples $(250 \mathrm{ml})$ of milk produced in the morning and evening were collected. A 50-ml sub-sample was stored at $4{ }^{\circ} \mathrm{C}$ with a preservative (2-bromo-2-nitro-1,3-propanediol, Aldrich Chemistry, USA) for milk components analysis and somatic cells count. The remaining $200 \mathrm{ml}$ were stored at $-20^{\circ} \mathrm{C}$ for fatty acids analysis. Milk production data were obtained by interview questionnaire and farm records.

Pastures in GS and MX systems were both sown and improved natural pastures, the average botanical composition being: Lolium perenne, 70-75\%, Trifolium repens, $5-10 \%$, Bromus spp., 3-5\%, and 5-10\% of others species. All farms in the GS and MX systems employed strip grazing.

Pasture DM intake was indirectly estimated from cows' milk production and live weight as follows (Baker 1982):

Pasture DM intake $=\frac{M E m+M E m l+M E L w-C o n c M E}{\text { Pasture } M E}$

where MEm, MEml and MELw are the estimated Metabolizable Energy (ME) requirements for maintenance, milk yield and live weight change, respectively (AFRC 1993). ConcME and Pasture ME correspond to ME supplied by the concentrate supplement and pasture $\mathrm{ME}$ is the estimated ME concentration of pasture samples of each sampling.

Table 1. Criteria for selecting the farms that participated in the study and characteristics of each production system. Criterios de selección y características de producción de los predios participantes en el estudio.

Criteria for farm selection

- Farm located in the Los Ríos region

- Similar period of confinement during lactation (within mixed system)

- Similar period of grazing (within grazing and mixed systems)

- Breed (Holstein Friesian)

- Production records available

- Official milk production control

- Similar farm size within each system

- Producer interest in participating in the study

\begin{tabular}{|c|c|c|}
\hline \multicolumn{3}{|c|}{ System characteristics } \\
\hline Grazing & Mixed & Total Mixed Ration \\
\hline Milking cows: $185 \pm 13$ & Milking cows: $382 \pm 28$ & Milking cows: $437 \pm 44$ \\
\hline $\begin{array}{l}\text { Grazing all year around } \\
\text { Strip grazing }\end{array}$ & $\begin{array}{l}\text { Grazing in autumn, spring and summer. } \\
\text { Strip Grazing } \\
\text { Confinement in winter }\end{array}$ & $\begin{array}{l}\text { Confinement all year around. Fresh pasture } \\
\text { offered cut }\end{array}$ \\
\hline $\begin{array}{l}\text { Concentrate offered in parlour } \\
\text { Conserved forage supplemented in autumn } \\
\text { and winter. Summer catch crops (turnips) }\end{array}$ & $\begin{array}{l}\text { Concentrate offered in parlour and } \\
\text { TMR in confinement during winter } \\
\text { Conserved forage supplemented } \\
\text { in autumn and winter. } \\
\text { Pasture irrigation in summer }\end{array}$ & Cows fed a total mixed ration (TMR) \\
\hline $\begin{array}{l}\text { All-year around calving and Seasonal } \\
\text { calving }\end{array}$ & Seasonal calving & All-year around calving \\
\hline
\end{tabular}


Pasture availability was estimated through electronic plate meter (F200, Farmworks, Fielding, New Zealand). Feeds were classified as conserved forage or concentrate (Lanuza 2011). Amounts of concentrate and conserved forage (silage, hay, etc.) offered were calculated from production records at each farm.

Samples of mixed ration were obtained from TMR farms at each monthly visit, and from the MX farms during the winter months visits. In case of the GS farms, and the MX farms during the spring, summer and autumn, the composition of the diet offered to cows at each farm was estimated from the amounts of each individual feed offered to the animals. Samples of the individual feedstuffs offered to the animals at each farm were obtained at each monthly farm visit. Simulated grazed pasture samples were collected on pasture strips. Samples of estimated diets were then reconstructed by mixing samples of each individual ingredient according to its proportion in the estimated diet. These composite samples were used for chemical and fatty acids analysis. A total of 162 samples (nine samples per 18 months) were analysed.

\section{CHEMICAL AND FATTY ACIDS ANALYSES}

Chemical and fatty acids analyses were conducted at Instituto de Investigaciones Agropecuarias (INIA), Chile. Dry matter (DM), crude protein (CP), EE and ash were determined as by AOAC (2005). Digestible Organic matter was estimated from in vitro digestibility obtained according to Tilley and Terry (1963). Neutral detergent fibre (NDF) was determined according to Sadzawka et al (2007). Milk fat, protein and lactose were analysed by near infrared spectroscopy (MILKOSCAN'TM, Foss Electrics, Hillerød, Denmark). Somatic cells were counted with a FOSSOMATIC ${ }^{\text {TM }}$ analyser.

Fat was extracted from milk according to Rico et al (2007) and from feed samples as per Bligh and Dyer (1959) modified by Lumley and Colwell (1991). Extracted milk and feed fatty acids were methylated as by Ichihara et al (1996) and Hartman and Lago (1973), respectively. Samples were analysed by gas chromatography equipped with an FID detector (Shimadzu model GC 2010 Plus). Separation was conducted using a capillary column (SPtm-2560, Sigma-Aldrich, USA, $100 \mathrm{~m} \mathrm{x} 0.25$ mm x $0.2 \mu \mathrm{m}$ ) with an initial oven temperature of $140{ }^{\circ} \mathrm{C}$ and a $4{ }^{\circ} \mathrm{C}$ min $^{-1}$ ramp until $240{ }^{\circ} \mathrm{C}$. Injector and detector temperatures were set at $260{ }^{\circ} \mathrm{C}$. Helium was used as carrier gas at a flow rate of $0.5 \mathrm{~mL} \mathrm{~min}^{-1}$. Injector split was set at 100:1. A mixture of fatty acid methyl esters (Supelco 37 Component FAME Mix, Supelco Analytical, USA), CLA ethyl ester (9c,11tr-Octadecadienoic, Larodan Fine Chemicals, Sweden), trans-11-vaccenic methyl ester (Perkin Elmer, USA), PUFA-2 (Supelco Analytical, USA) were used as external standards, and 19:0 (NU-CheckPrep, INC, Elysian, USA) was added before extraction as internal standard.

\section{STATISTICAL ANALYSIS}

Data were analysed by repeated measures with JMP®, with feeding system and month (time), and their interaction, as fixed effects. Farm was included as a random effect nested within feeding system:

response $=$ intercept + feeding system + month + interaction + farm (feeding system, random $)+$ residual

Non-significant $(\mathrm{P}>0.10)$ interactions were eliminated. When the effect of the feeding system was significant $(\mathrm{P}<0.05)$, least-square means were separated by Tukey's HSD test.

\section{RESULTS}

\section{FEED COMPOSITION}

Accumulated precipitation and low and high temperatures recorded during the study are shown in table 2. In general, accumulated precipitation was lower than historical for this area $(1.330 \mathrm{~mm})$. Low temperature in the autumn and winter of Year 2 were lower than in Year 1 (table 2). Pre and post-grazing sward heights of GS and MX systems are presented in the table 2 .

Estimated intake of each dietary component is shown in table 3. The GS and MX systems were highest in fresh forage, and the TMR system had the highest amount of conserved forages and concentrate offered. Seasonal variation of fresh forage ( $\mathrm{kg}$ Dry Matter $\mathrm{d}^{-1}$ ) by production system is shown in figure 1 . The TMR system had the lowest fresh forage: concentrate ratio $(\mathrm{F}: \mathrm{C})$, whereas $\mathrm{GS}$ had the highest. The GS system included fodder turnips in the summer (month 10: $5 \mathrm{~kg} \mathrm{DM} \mathrm{d}^{-1}$ and month 11:2.8 $\mathrm{kg} \mathrm{DM} \mathrm{d}^{-1}$ ). The total dry matter (DM) intake was higher in TMR than GS and MX.

The TMR diet had the highest estimated DM and the lowest NDF content (table 3 ). The grazing system had the lowest dietary $c-9 c-12-18: 2$. In contrast, GS and MX had higher $c-9 c-12 c-15-18: 3$ ( $\alpha$-linolenic) concentration than TMR in the diet (table 3). The diet of GS had higher 20:0 concentration than TMR.

\section{MILK YIELD AND COMPOSITION}

The TMR system had higher milk yield than GS, with MX being intermediate (table 4). Fat percentage was highest in GS and lowest in MX. Milk protein was not affected by system. Lactose content was lowest in GS and highest in TMR. Urea content was higher in GS than TMR, and MX was intermediate. Somatic cell count (SCC) was higher in TMR than in the other two systems.

\section{MILK FATTY ACID COMPOSITION}

Milk from GS had lower $c-9 c-12-18: 2, n-6: n-3$ ratio and higher $\alpha$-linolenic than TMR whereas MX was intermediate 


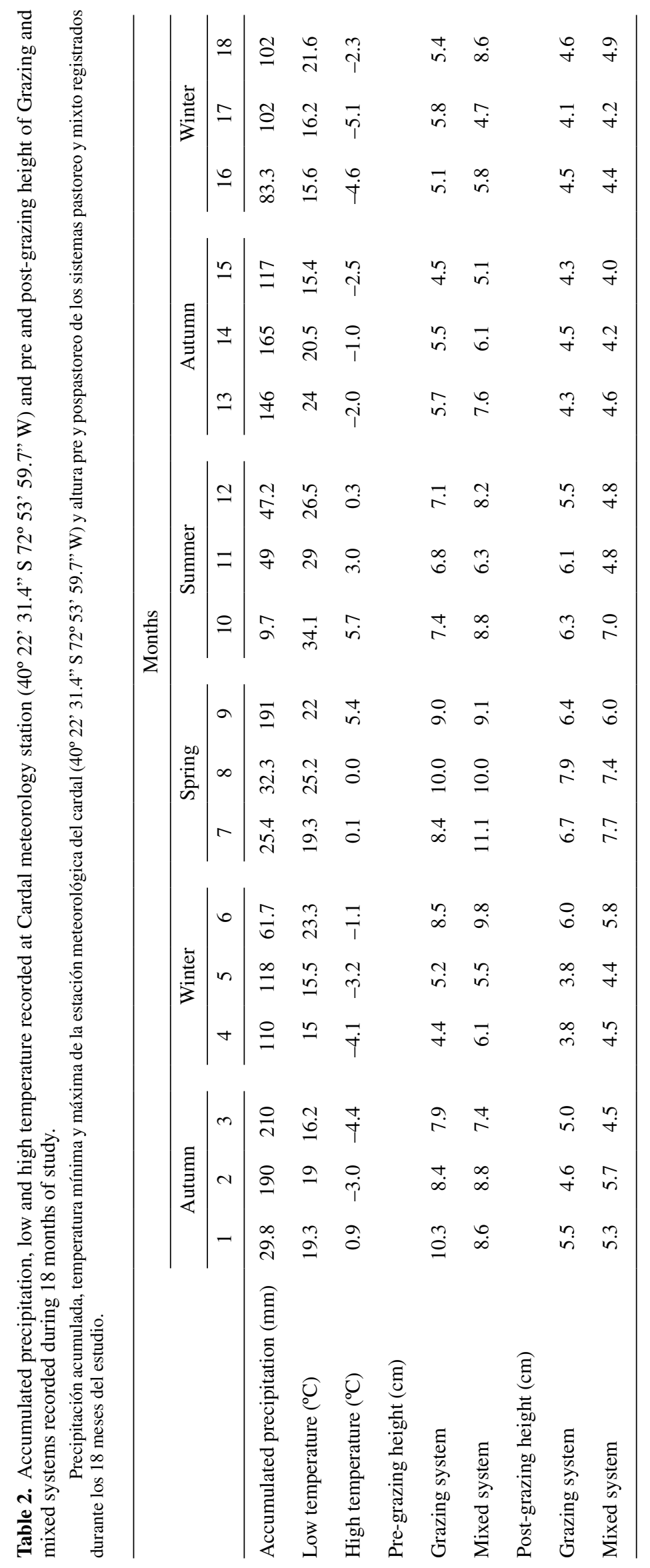




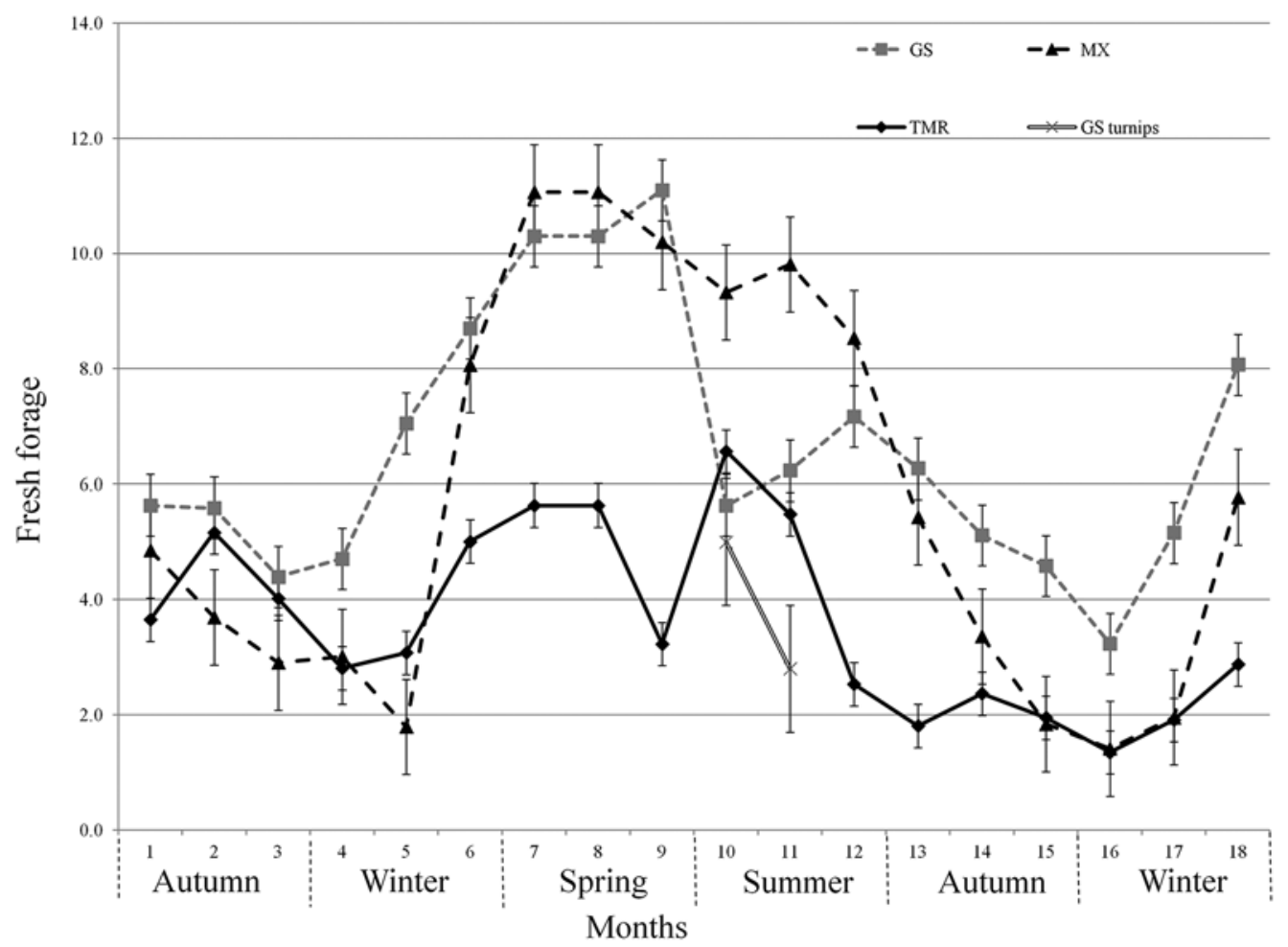

Figure 1. Seasonal variation of fresh forage production ( $k g$ Dry Matter $\mathrm{d}^{-1}$ ) by system. $\mathrm{GS}=\mathrm{Grazing}$ system; MX= Mixed system; $\mathrm{TMR}=$ Total Mixed Ration system. GS turnips= kg dry matter of turnips in Grazing systems.

Variación de producción de forraje fresco en la temporada $\left(\mathrm{kg}\right.$ materia seca $\left.\mathrm{d}^{-1}\right)$ por sistema de producción. GS= Sistema pastoril; MX= Sistema mixto; TMR= Ración totalmente mezclada. GS nabo= kg materia seca de nabo en sistema pastoril.

(table 5). Milk from GS and MX systems had higher RA and $c-6 c-9 c-12-18: 3$ than milk from TMR.

The time by system interaction was significant for total saturated fatty acids (SFA, figure 2), 8:0, 10:0, 11:0, 12:0, 13:0, 14:0, 15:0, 16:0, 18:0, total unsaturated fatty acids (UFA), $c-9-18: 1$, RA (figure 3 ) and $n-6$ fatty acids (figure 4).

In months 1 and 3, GS had higher total saturated fatty acids than TMR, with MX being intermediate whereas in the month $12 \mathrm{MX}$ was higher than TMR and GS was intermediate (figure 2).

In late winter and spring there was an increase in RA in GS and MX (figure 3) whereas differences in $n-6$ fatty acids were observed during the two autumns of the study (figure 4), with GS being lower than TMR in the autumn of the first year and the mid and late autumn of the second year.

\section{DISCUSSION}

The milk fat content of GS system was similar to what was reported by Calvache (2009) for the same Chilean area and it is higher to what was reported by Palladino et al 2010 and White et al (2001) for Holstein Friesian breed (3.3-3.5\%). The three systems were higher to values reported by Pinto et al (1998) from milk of 16 dairy plants of regions of south of Chile (3.53\%).

The grazing systems had higher milk urea $\mathrm{N}$ concentration. Urea is the primary form of $\mathrm{N}$ excretion in mammals, and high concentration of milk urea $\mathrm{N}$ has long been known to reflect inefficient utilization of dietary $\mathrm{N}$ by ruminants (Broderick and Clayton 1997). When ammonia release rate in the rumen exceeds its rate of incorporation into microbial amino acids, excess ammonia is absorbed through the rumen wall and converted to urea in the liver, most of which is eliminated in urine (Wallace et al 1997). Even though the numerical differences in estimated dietary CP content among systems were not significant, protein in local pastures has been shown to be highly degradable (Valderrama and Anrique 2011), which could make $\mathrm{N}$ utilisation in the rumen inefficient in the GS system. Regarding SCC, housing increases the risk of environmental contamination associated with subclinical mastitis, which might explain the higher SCC in TMR ${ }^{1}$ (Golbert et al 1992).

\footnotetext{
Olivo CJ, LI Beck, A Mossat Gabbi, P Santini Charão, MF Sobczak, LF Gomes Uberty, JW Dürr, R Araújo Filho. 2005.Composition and somatic cell count of milk in conventional and agro-ecological farms: a comparative study in Depressão Central, Rio Grande do Sul state, Brazil. Livest Res Rural Dev 17 Article \#72. Retrieved April 28, 2014, http://www.lrrd.org//rrd17/6/oliv17072.htm
} 


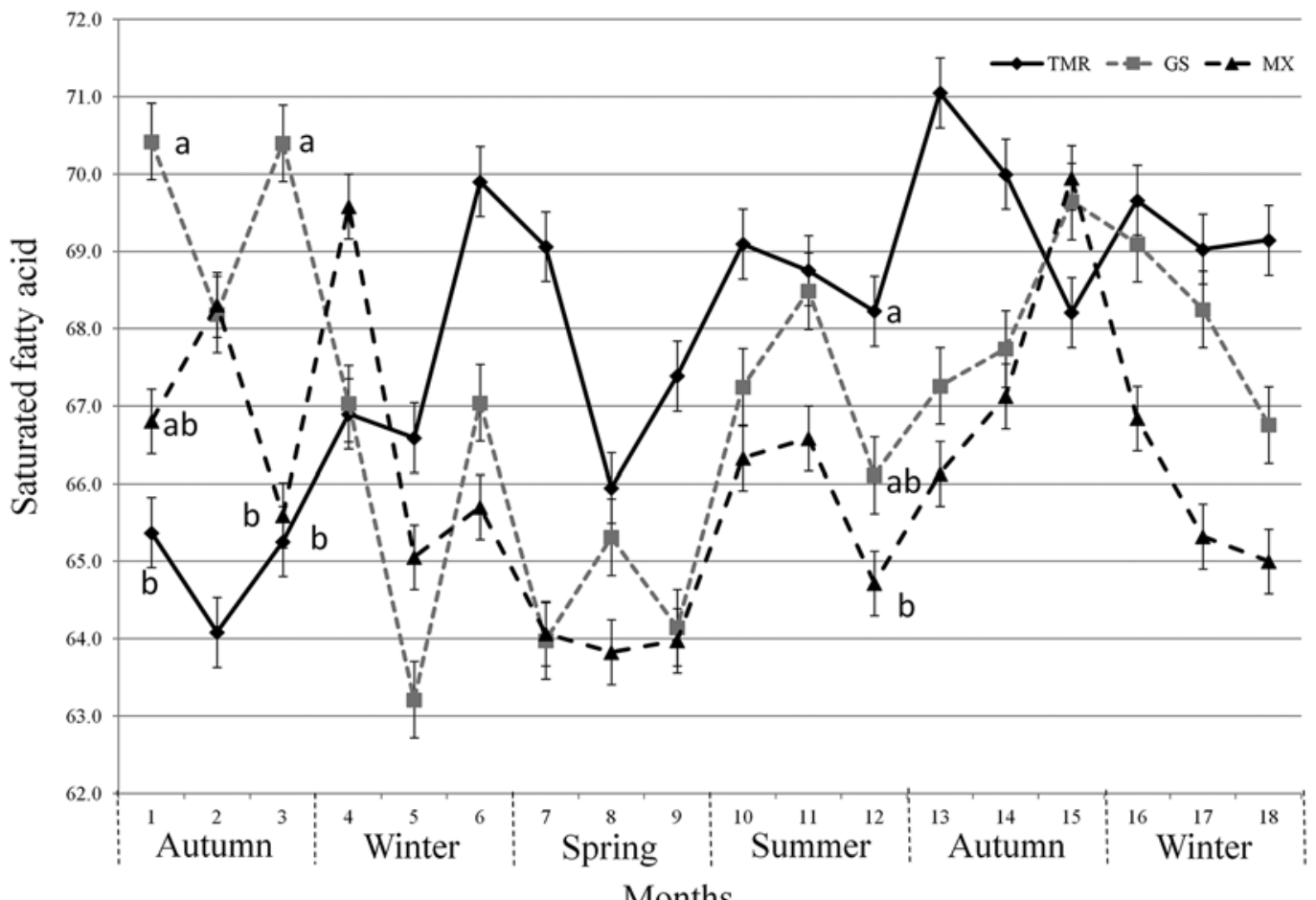

Figure 2. Seasonal variation of saturated fatty acids ( $100 \mathrm{~g}^{-1}$ of total fatty acids) by production system. GS= Grazing systems; $\mathrm{MX}=$ Mixed system; TMR = Total Mixed Ration system. ${ }^{\mathrm{ab}}$ Common letter within each month indicates no significant difference $(\mathrm{P}>0.05)$.

Variación de ácidos grasos saturados en la temporada ( $100 \mathrm{~g}^{-1}$ de ácidos grasos totales) por sistema de producción. GS= Sistema pastoril; MX= Sistema mixto; TMR= Ración totalmente mezclada. Letras iguales dentro del mes no indican diferencia significativa $(\mathrm{P}>0.05)$.

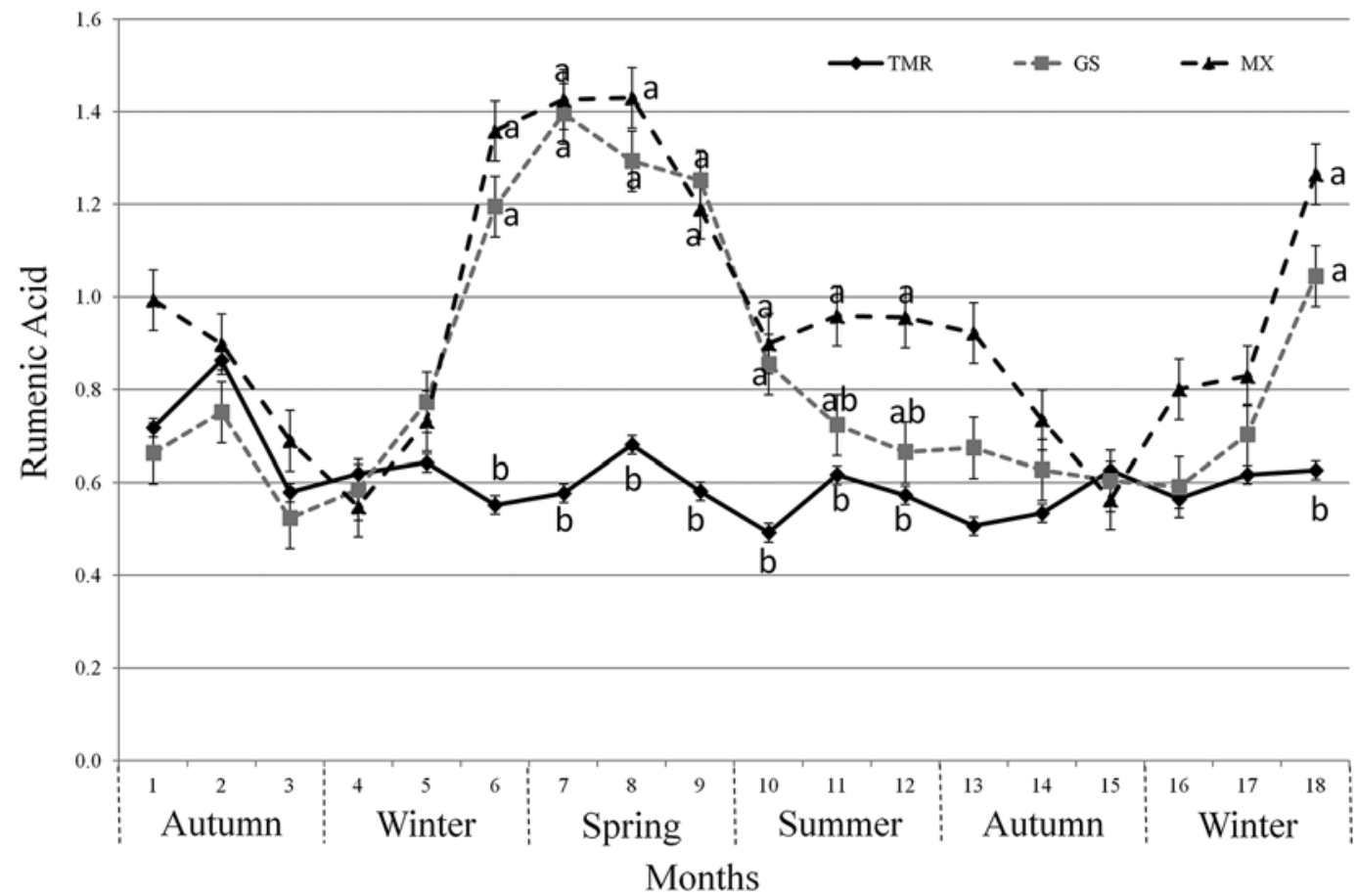

Figure 3. Seasonal variation of Rumenic acid ( $100 \mathrm{~g}^{-1}$ of total fatty acids) by production system. GS= Grazing systems; MX= Mixed system; TMR= Total Mixed Ration system. ${ }^{\text {ab }}$ Common letter within each month indicates no significant difference $(\mathrm{P}>0.05)$.

Variación de ácido ruménico en la temporada ( $100 \mathrm{~g}^{-1}$ de ácidos grasos totales $)$ por sistema de producción. GS= Sistema pastoril; MX= Sistema mixto; TMR= Ración totalmente mezclada. Letras iguales dentro del mes no indican diferencia significativa $(\mathrm{P}>0,05)$. 
Table 3. Estimated amount of feeds offered and composition and fatty acids content of estimated diet in each feeding system.

Cantidad estimada de alimentos ofrecidos y perfil de ácidos grasos de la dieta para cada sistema.

\begin{tabular}{|c|c|c|c|c|c|c|c|}
\hline \multirow[b]{2}{*}{ Feed (DM) } & \multicolumn{3}{|c|}{ Production system } & \multirow[b]{2}{*}{ S.E.M } & \multicolumn{3}{|c|}{$P$-value } \\
\hline & Grazing & Mixed & $\begin{array}{c}\text { Total Mixed } \\
\text { Ration }\end{array}$ & & Time $(\mathrm{T})$ & System $(\mathrm{S})$ & $\mathrm{T} \times \mathrm{S}$ \\
\hline Fresh forage $\mathrm{kg} \mathrm{d}^{-1}$ & $6.62^{\mathrm{a}}$ & $5.78^{\mathrm{a}}$ & $3.69^{\mathrm{b}}$ & 0.43 & 0.058 & 0.007 & 0.63 \\
\hline Conserved forage $\mathrm{kg} \mathrm{d}^{-1}$ & $3.66^{\mathrm{b}}$ & $4.17^{\mathrm{b}}$ & $7.24^{\mathrm{a}}$ & 0.40 & 0.004 & 0.002 & 0.021 \\
\hline Concentrate $\mathrm{kg} \mathrm{d}^{-1}$ & $4.84^{\mathrm{b}}$ & $6.76^{\mathrm{b}}$ & $10.00^{\mathrm{a}}$ & 0.64 & 0.002 & 0.004 & $<0.001$ \\
\hline Fresh forage: concentrate ratio & $1.39^{\mathrm{a}}$ & $0.90^{\mathrm{b}}$ & $0.38^{\mathrm{c}}$ & 0.096 & 0.17 & 0.001 & 0.91 \\
\hline Turnips kg d ${ }^{-1}$ & 0.44 & --- & --- & --- & --- & --- & --- \\
\hline Total DMI kg d ${ }^{-1}$ & $15.6^{\mathrm{b}}$ & $16.7^{\mathrm{b}}$ & $20.8^{\mathrm{a}}$ & 4.108 & 0.51 & 0.001 & 0.47 \\
\hline \multicolumn{8}{|l|}{ Diet composition } \\
\hline Dry Matter $\%$ & $24.7^{\mathrm{b}}$ & $29.5^{\mathrm{ab}}$ & $34.2^{\mathrm{a}}$ & 1.36 & 0.005 & 0.006 & 0.94 \\
\hline Crude Protein \% DM & 20.0 & 19.6 & 18.6 & 1.09 & 0.91 & 0.63 & 0.94 \\
\hline Digestible Organic Matter \% DM & 75.0 & 74.6 & 76.3 & 0.50 & 0.005 & 0.18 & 0.30 \\
\hline Neutral Detergent Fibre \% DM & $40.5^{\mathrm{a}}$ & $37.8^{\mathrm{a}}$ & $31.5^{\mathrm{b}}$ & 1.52 & 0.71 & 0.007 & 0.23 \\
\hline Ether extract \% DM & 3.24 & 3.14 & 3.22 & 0.214 & 0.013 & 0.93 & 0.75 \\
\hline \multicolumn{8}{|c|}{ Fatty acids content g $100 \mathrm{~g}^{-1}$ of total fatty acids } \\
\hline 14:0 & 1.46 & 1.19 & 1.19 & 0.12 & 0.001 & 0.28 & 0.021 \\
\hline 16:0 & 31.1 & 30.7 & 26.2 & 3.32 & 0.89 & 0.29 & 0.53 \\
\hline$c-9-16: 1$ & $0.85^{\mathrm{a}}$ & $0.74^{\mathrm{ab}}$ & $0.48^{\mathrm{b}}$ & 0.075 & 0.93 & 0.038 & 0.68 \\
\hline 18:0 & $10.0^{\mathrm{a}}$ & $9.34^{\mathrm{a}}$ & $5.21^{\mathrm{a}}$ & 1.91 & 0.001 & 0.20 & 0.078 \\
\hline$c-9-18: 1$ & 18.6 & 16.3 & 23.3 & 2.40 & 0.016 & 0.15 & 0.021 \\
\hline$c-9 c-12-18: 2$ & $19.4^{\mathrm{b}}$ & $27.1^{\mathrm{ab}}$ & $33.1^{\mathrm{a}}$ & 2.90 & 0.001 & 0.022 & 0.47 \\
\hline$c-9 c-12 c-15-18: 3$ & $17.0^{\mathrm{a}}$ & $14.3^{\mathrm{ab}}$ & $9.36^{\mathrm{b}}$ & 8.576 & 0.21 & 0.019 & 0.079 \\
\hline 20:0 & $0.89^{\mathrm{a}}$ & $0.62^{\mathrm{ab}}$ & $0.59^{\mathrm{b}}$ & 0.061 & 0.21 & 0.025 & 0.18 \\
\hline$c-9-20: 1$ & 0.19 & 0.085 & 0.10 & 0.091 & 0.67 & 0.67 & 0.81 \\
\hline
\end{tabular}

${ }^{\mathrm{ab} C o m m o n}$ letter within a row indicates no significant difference among production systems $(\mathrm{P}>0.05)$.

Fresh forage: grazing and/or cut Lolium multiflorum pasture (Total Mixed Ration system).

Conserved forage: pasture and corn silage, pasture and alfalfa.

SEM: Standard error of the mean;

${ }^{\mathrm{ab}}$ Letras iguales dentro de la fila indica ausencia de diferencias significativas entre sistemas de producción $(\mathrm{P}>0,05)$.

Forraje fresco: pastoreo o soiling de Lolium multiflorum (Sistema ración totalmente mezclada).

Forraje conservado: pradera y ensilaje de maíz, pradera y alfalfa.

SEM: Error estándar.

Total SFA were similar to values reported by Pinto et al (2002) from milk fat from dairy plants in the south of Chile. Several studies indicated that concentrate supplementation increased SFA and reduced UFA content (Rego et al 2004, Bargo et al 2006) in the present study, this relation was no clear (figure 2).

The low proportion of $c-9 c-12-18: 2$ and higher proportion of $\alpha$-linolenic in milk fat from GS can be explained by the dietary concentration of $c-9 c-12-18: 2$ and $\alpha$-linolenic fatty acids of GS (table 3). Dietary concentration of fatty acids is related to fresh forage intake of each system, where fresh grass contains a high proportion $(50 \%-75$ $\%)$ of total FA content as $\alpha$-linolenic, whereas grains have higher concentrations of $c-9 c-12-18: 2$ (Elgersma et al 2006). Some authors have reported similar results in cows fed cut fresh forage (Ferlay et al 2006), grazing cows (Bargo et al 2006), and TMR complemented with $12 \mathrm{~h}$ grazing (Morales-Almaráz et al 2010). White et al (2001) and Gómez-Cortés et al (2009) reported that higher concentrate in the diet resulted in higher concentration in milk fat of $n-6$ fatty acids than grazing. Other reports indicate that grazing increased $\alpha$-linolenic content in milk fat (Wyss et al 2010, Morales-Almaráz et al 2010, Rutkowska et al 2012). In this respect, increments in $\alpha$-linolenic would represent a benefit of diets based on pasture from the point of view of milk health attributes (Gómez-Cortés et al 2009).

Milk fat from GS and MX had approximately 50\% more RA than milk fat from TMR (table 5). Rumenic acid is produced as an intermediate of the biohydrogenation process occurring in the rumen, where dietary unsaturated fatty acids (mainly $c-9 c-12-18: 2$ and $\alpha$-linolenic) undergo 
Table 4. Milk yield and components by production system.

Cantidad y componentes de leche por sistema de producción.

\begin{tabular}{|c|c|c|c|c|c|c|c|}
\hline \multirow[b]{2}{*}{ Response } & \multicolumn{3}{|c|}{ Production Systems } & \multirow[b]{2}{*}{ S.E.M } & \multicolumn{3}{|c|}{$P$-value } \\
\hline & Grazing & Mixed & $\begin{array}{c}\text { Total Mixed } \\
\text { Ration }\end{array}$ & & Time $(\mathrm{T})$ & System (S) & $\mathrm{T} \times \mathrm{S}$ \\
\hline Milk per cow kg d ${ }^{-1}$ & $23.0^{\mathrm{b}}$ & $25.3^{\mathrm{ab}}$ & $28.7^{\mathrm{a}}$ & 7.128 & 0.000 & 0.016 & 0.025 \\
\hline Fat $\%$ & $4.14^{\mathrm{a}}$ & $3.68^{\mathrm{b}}$ & $3.84^{\mathrm{ab}}$ & 0.184 & 0.000 & 0.043 & 0.004 \\
\hline Protein $\%$ & 3.47 & 3.43 & 3.39 & 0.0353 & 0.000 & 0.064 & 0.052 \\
\hline Lactose $\%$ & $4.74^{\mathrm{c}}$ & $4.85^{\mathrm{b}}$ & $4.92^{\mathrm{a}}$ & 0.0188 & 0.011 & $<0.001$ & 0.122 \\
\hline Urea $\mathrm{g} \mathrm{ml}^{-1}$ & $0.308^{\mathrm{a}}$ & $0.298^{\mathrm{ab}}$ & $0.284^{\mathrm{b}}$ & 0.00651 & 0.000 & 0.006 & 0.069 \\
\hline Somatic cell count $\times 10^{3} \mathrm{cel} \mathrm{ml}^{-1}$ & $172.7^{\mathrm{b}}$ & $163.9^{\mathrm{b}}$ & $210.7^{\mathrm{a}}$ & 16.8 & 0.001 & 0.013 & 0.001 \\
\hline
\end{tabular}

${ }^{\mathrm{ab}}$ Common letter within a row indicates no significant difference among production systems $(\mathrm{P}>0.05)$.

SEM: Standard error of the mean.

ab Letras iguales dentro de la fila no indican diferencia significativa entre sistemas de producción $(\mathrm{P}>0,05)$.

SEM: Error estándar.

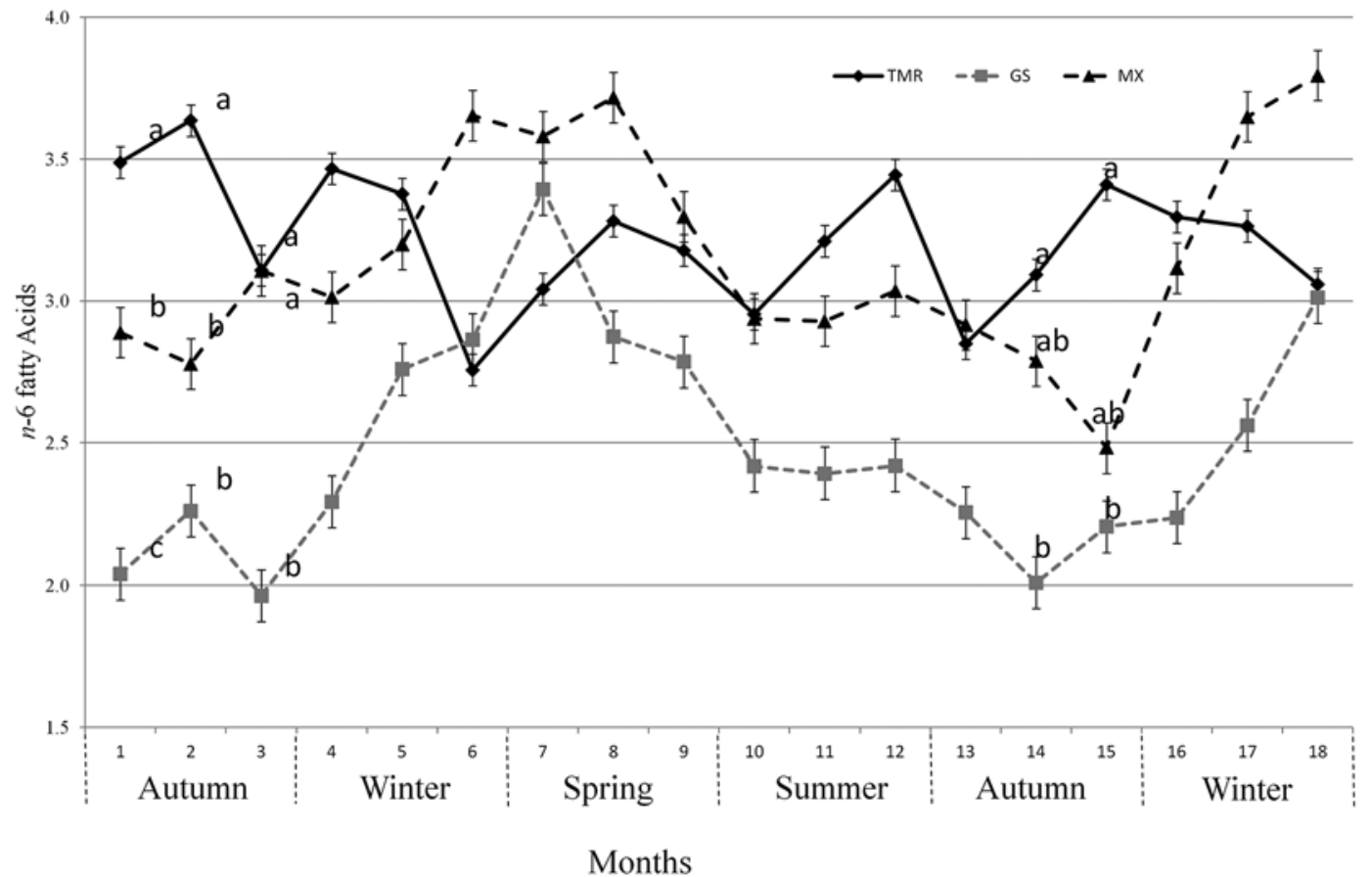

Figure 4. Seasonal variation of $\mathrm{n}-6$ fatty acids ( $\mathrm{g} 100 \mathrm{~g}^{-1}$ of total fatty acids) by production system. GS= Grazing systems; MX= Mixed system; TMR $=$ Total Mixed Ration system. ${ }^{\text {ab }}$ Common letter within each month indicates no significant difference $(\mathrm{P}>0.05)$.

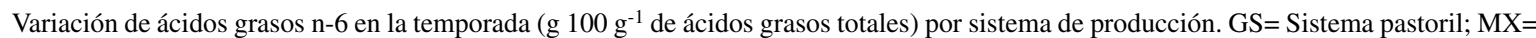
Sistema mixto; TMR= Ración totalmente mezclada. Letras igual dentro del mes no indican diferencia significativa $(\mathrm{P}>0,05)$.

successive steps of isomerisation and reduction (Lock and Bauman, 2004, Kalač and Samková, 2010). Most RA in milk fat is actually synthesised by endogenous conversion of $t$-11-18:1 (trans-vaccenic acid) by the enzyme $\Delta-9$ desaturase in mammary gland (Bauman and Griinari, 2003), $t-11-18: 1$ also being an intermediate of ruminal biohydrogenation. The positive effect of pasture intake on RA in milk fat has been previously reported (Kelly et al
1998, Ferlay et al 2006, Gómez-Cortés et al 2009). On the other hand, RA content is negatively affected by the level of concentrate in the diet (Shingfield et al 2010, Aldai et al 2013). Rumenic acid content in milk fat in GS and MX treatments in the present study are somewhat higher than those reported by Aviléz et al (2012, 2013), who also worked with grazing systems under the conditions of Southern Chile. 
Table 5. Fatty acid composition ( $\mathrm{g} 100 \mathrm{~g}^{-1}$ of total fatty acids by production system.

Perfil de ácidos grasos ( $100 \mathrm{~g}^{-1}$ de ácidos grasos totales) por sistema de producción.

\begin{tabular}{|c|c|c|c|c|c|c|c|}
\hline \multirow[b]{2}{*}{ Fatty acid } & \multicolumn{3}{|c|}{ Productive Systems } & \multirow[b]{2}{*}{ S.E.M } & \multicolumn{3}{|c|}{$P$-value } \\
\hline & Grazing & Mixed & $\begin{array}{c}\text { Total Mixed } \\
\text { Ration }\end{array}$ & & Time $(\mathrm{T})$ & System (S) & $\mathrm{T} \times \mathrm{S}$ \\
\hline Total SFA & 67.19 & 66.17 & 67.98 & 0.0753 & 0.018 & 0.30 & 0.0006 \\
\hline $4: 0$ & 2.03 & 1.92 & 1.91 & 0.052 & 0.61 & 0.26 & 0.20 \\
\hline $6: 0$ & 1.37 & 1.29 & 1.32 & 0.033 & 0.11 & 0.34 & 0.080 \\
\hline $8: 0$ & 0.98 & 0.94 & 0.95 & 0.043 & 0.0003 & 0.84 & 0.015 \\
\hline 10:0 & 2.45 & 2.40 & 2.53 & 0.181 & 0.0001 & 0.89 & 0.0005 \\
\hline 11:0 & 0.29 & 0.29 & 0.30 & 0.029 & 0.0001 & 0.92 & 0.001 \\
\hline $12: 0$ & 3.07 & 3.02 & 3.26 & 0.276 & 0.0002 & 0.81 & 0.0002 \\
\hline $13: 0$ & 0.16 & 0.17 & 0.19 & 0.025 & 0.27 & 0.62 & 0.009 \\
\hline $14: 0$ & 10.77 & 10.63 & 11.03 & 0.483 & 0.0001 & 0.84 & 0.002 \\
\hline $15: 0$ & 1.08 & 1.12 & 1.19 & 0.082 & 0.017 & 0.70 & 0.0008 \\
\hline $16: 0$ & 30.54 & 31.04 & 32.34 & 0.822 & 0.027 & 0.35 & 0.033 \\
\hline $17: 0$ & 0.54 & 0.61 & 0.61 & 0.049 & 0.0001 & 0.53 & 0.29 \\
\hline 18:0 & 13.75 & 12.58 & 12.19 & 1.085 & 0.0001 & 0.60 & 0.0005 \\
\hline $20: 0$ & 0.17 & 0.15 & 0.15 & 0.010 & 0.064 & 0.64 & 0.26 \\
\hline UFA & 32.31 & 33.34 & 31.58 & 0.756 & 0.031 & 0.32 & 0.0006 \\
\hline$c-9-14: 1$ & 0.91 & 0.90 & 0.93 & 0.086 & 0.018 & 0.97 & 0.48 \\
\hline$c-9-16: 1$ & 1.28 & 1.24 & 1.27 & 0.071 & 0.0007 & 0.94 & 0.15 \\
\hline$c-9-17: 1$ & 0.22 & 0.25 & 0.22 & 0.017 & 0.99 & 0.35 & 0.57 \\
\hline$t-11-18: 1$ & 0.88 & 1.34 & 0.70 & 0.208 & 0.50 & 0.60 & 0.28 \\
\hline$c-9-18: 1$ & 25.50 & 25.71 & 24.61 & 0.594 & 0.12 & 0.43 & 0.003 \\
\hline$c-7-18: 1$ & 0.05 & 0.12 & 0.29 & 0.144 & 0.37 & 0.52 & 0.22 \\
\hline$t-9 t-12-18: 2$ & 0.27 & 0.31 & 0.26 & 0.025 & 0.71 & 0.33 & 0.52 \\
\hline$c-9 c-12-18: 2$ & $1.30^{\mathrm{b}}$ & $1.81^{\mathrm{ab}}$ & $2.28^{\mathrm{a}}$ & 0.143 & 0.15 & 0.008 & 0.058 \\
\hline$c-9 c-12 c-15-18: 3$ & $0.74^{\mathrm{a}}$ & $0.69^{\mathrm{ab}}$ & $0.53^{\mathrm{b}}$ & 0.049 & 0.12 & 0.043 & 0.35 \\
\hline$c-6 c-9 c-12-18: 3$ & $0.10^{\mathrm{a}}$ & $0.08^{\mathrm{a}}$ & $0.073^{\mathrm{b}}$ & 0.0032 & 0.28 & 0.005 & 0.35 \\
\hline$c-9 t-11-18: 2$ & $0.83^{\mathrm{a}}$ & $0.96^{\mathrm{a}}$ & $0.61^{\mathrm{b}}$ & 0.048 & 0.27 & 0.006 & 0.008 \\
\hline Unidentified & 0.49 & 0.49 & 0.44 & 0.019 & 0.0001 & 0.13 & 0.58 \\
\hline$n-3$ & $0.74^{\mathrm{a}}$ & $0.70^{\mathrm{ab}}$ & $0.53^{\mathrm{b}}$ & 0.049 & 0.11 & 0.043 & 0.35 \\
\hline$n-6$ & 2.49 & 3.16 & 3.21 & 0.21 & 0.94 & 0.088 & 0.019 \\
\hline$n-6: n-3$ & $3.41^{\mathrm{b}}$ & $4.75^{\mathrm{ab}}$ & $6.64^{\mathrm{a}}$ & 0.59 & 0.042 & 0.023 & 0.27 \\
\hline
\end{tabular}

${ }^{\mathrm{ab} C o m m o n}$ letter within a row indicates no significant difference $(\mathrm{P}>0.05)$. SEM: Root mean squared error; SFA: saturated fatty acids; UFA: unsaturated fatty acids; $n-6: n-3$ : fatty acid ratio.

Letras iguales dentro de la fila no indican diferencia significativa $(\mathrm{P}>0,05)$. SEM: Error del cuadrado medio; SFA: ácidos grados saturados; UFA: ácidos grasos insaturados; $n-6: n-3$ : relación ácidos grasos.

Considerable attention has been paid to the relative proportion of $n-6$ and $n-3$ fatty acids, as diets with $n-6: n-$ 3 ratios higher than 4.0 have been suggested to increase risk for certain cancers and coronary heart disease (British Department of Health, 1994, Hibbeln et al 2006). In this respect, only milk from the GS system had a $n-6: n-3$ ratios lower than 4.0 (table 5). Similar results were reported by Khan et al (2012), who speculated that the decrease they observed in $\alpha$-linolenic and total $n-3$ content, and the increase in the $n-6: n-3$ ratio in milk fat, were the results of reduced $\alpha$-linolenic intake.
In late winter and spring there was an increase in RA in GS and MX (figure 3). This increase coincided and is likely due to increase of pasture intake in those seasons (figure 1), with greatest pre and post-grazing pasture heights (table 2). Pasture production in southern Chile varies amply throughout the year, with low growth rates in winter and dry summers (Balocchi1986). Other studies revealing seasonal variation in CLA content of milk fat with the highest concentrations in warm seasons in grazing cows and the lowest concentrations in winter have been reported (Lock and Garnsworthy 2003, Elgersma et al 2006, Collomb et al 2008, Wyss et al 2010). 
Jahreis et al (1997) compared conventional farming with high external inputs of fertiliser and concentrates, with or without grazing during summer, against low external input organic farming with summer grazing. They found that organically produced milk had the highest content of RA in milk fat, especially during May through September, which was the grazing period. In another study, milk from a grazing system and an organic, low external input system, had higher concentrations of nutritionally desirable fatty acids (RA and $\alpha$-linolenic) compared to milk from a high-input system (Butler et al 2008). In agreement, Dhiman et al (1999) indicated that increasing the proportion of grazed grass from pasture in the diet of dairy cows linearly increased the RA content of milk. Similarly, White et al (2001) found that cows grazing warm-season crabgrass (Digitaria sanguinalis) supplemented with $5.5 \mathrm{~kg}$ of commercial concentrate/cow per day produced significantly higher RA concentrations in milk compared to confinement-fed cows.

During the summer months (February and March), RA was higher in MX than in TMR, whereas GS was intermediate. High RA content in milk from MX systems could be due to: (1) higher pasture intake and (2) pasture of better quality in MX compared to GS as a result of irrigation (Nissen and Robert 2009). Irrigation also increases pasture growth rate, and as a consequence pasture intake in MX (figure 1). Content of $c-9 c-12 c-15-18: 3$ is affected by season and date of cutting, with the highest values in spring (Dewhurst et al 2001), and consequently concentrations of all CLA isomers in milk decrease as pastures mature (Aviléz et al 2012). In addition, during summer animals in GS were supplemented with higher proportion of fodder turnips (Brassica rapa) in the diet (figure 1). It is reported that inclusion of turnips decrease the RA concentration in the milk (Thomson et al 2000), and this might affect to RA content in GS.

Dietary content of linolenic acid is evidently central to explain differences among production systems in milk fat linolenic and rumenic acid. Nevertheless, differences in milk composition among the production systems studied can also be influenced by factors other than the diet. For example, the three production systems studied differed with regard to calving seasons (table 1), which caused variation among them with regard to lactation stage at different times of the year. Lactation stage is known to affect milk fat content (Phillips 2010). Regarding the fatty acids, several studies reported that there is an increase of 6:0 to 14:0 during the first 3 months of lactation and a decrease thereafter, whereas 18:0 fatty acids follow an inverted pattern (Kay et al 2005, Garnsworthy et al 2006, Stoop et al 2009, Bilal et al 2014). On the other hand, RA increased with lactation stage (Kay et al 2005, Stoop et al 2009). However, these authors indicate that changes in milk fat composition over lactation are not explained by changes in overall fat percentage.
The results of the present study should be interpreted with caution. Even though we selected farms as homogenous as possible within each system regarding aspects unrelated to feed management, they would evidently differ both in nutritional and non-nutritional aspects. Furthermore, as explained, estimation of intake of silage and supplements were done from each farm records and not thus not standardised among farms, and are therefore not strictly comparable.

Milk fat from grazing and mixed systems had higher $n-3$ and rumenic fatty acids concentrations, in particular during late winter and spring. Higher $n-3$ and RA content in grazing and mixed systems milk fat associated with high pasture intake in these systems. These results indicate that grazing contributes to improve milk nutritional quality.

\section{ACKNOWLEDGEMENTS}

This work was funded by FONDEF-Regional de la Región de Los Ríos D10R1012 and supported by Consorcio Lechero S.A. We thank Soledad Muñoz, Paolo Huircan, Betzabé Martinez and Ignacio Gallardo for their assistance with laboratory analyses. We are grateful to the following producers for their participation in this study: Jorge Carrasco, Paulina Carrasco, Maite Dufforc, Raúl Garcia, Pablo Kuschel, Luis Momberg, Enrique Romeny, Domingo Sanhueza and Integra S.A.

\section{REFERENCES}

AFRC, Agricultural and Food Research Council. 1993. Energy and Protein Requirements of Ruminants. An advisory manual prepared by the AFRC Technical Committee on Responses to Nutrients. CAB International, Wallingford, UK.

Albers R, R Van der Wielen. 2003. Effects of cis-9, trans-11 and trans-10, cis-12 conjugated linoleic acid (CLA) isomers on immune function in healthy men. Eur J Clin Nutr 57, 595-603.

Aldai N, M de Renobales, LJ Barron, JKG Kramer. 2013. What are the trans fatty acids issues in foods after discontinuation of industrially produced trans fats? Ruminant products, vegetable oils, and synthetic supplements. Eur J Lipid Sci Tech 115, 1378-1401.

AOAC, Association of Official Analytical Chemists. 2005. Official methods of analysis. $18^{\text {th }}$ ed. AOAC, Washington D.C., USA.

Avilez JP, P Escobar, C Díaz, G Von Fabeck, R Matamoros, F García, M Alonzo. 2012. Effect of extruded whole soybean dietary concentrate on conjugated linoleic acid concentration in milk in Jersey cows under pasture conditions. Span J Agric Res 10, 409-418.

Avilez, JP, G Von Fabeck, M Alonzo. 2013. Conjugated linoleic acid content in milk of Chilean Black Friesian cows under pasture conditions and supplemented with canola seed (Brassica napus) concentrate. Span J Agric Res 11, 747-758.

Baker RD. 1982. Estimating herbage intake from animal performance. In: Leaver Hurley JD (ed). Herbage Intake Handbook. British Grassland Society, Warwickshire, UK, Pp 77-93.

Balocchi O. 1986. Alternativas de producción de forraje suplementario. En: Anrique R (ed). Producción de forrajes. Facultad de Ciencias Agrarias, Universidad Austral de Chile, Valdivia, Chile, Pp 127-130.

Bargo F, JE Delahoy, GF Schroeder, LD Muller. 2006. Milk fatty acid composition of dairy cows grazing at two pasture allowances and supplemented with different levels and sources of concentrate. Anim Feed Sci Technol 125, 17-31.

Bauman DE, JM Griinari. 2003. Nutritional regulation of milk fat synthesis. Annu Rev Nutr 23, 203-227.

Bauman, DE, JW Perfield, KJ Harvatine, LH Baumgard. 2008. Regulation of fat synthesis by conjugated linoleic acid: lactation and the ruminant model. J Nutr Sci 138, 403-409. 
Bilal G, RI Cue, AF Mustafa, JF Hayes. 2014. Effects of parity, age at calving and stage of lactation on fatty acid composition of milk in Canadian Holsteins. Can J Anim Sci 94, 401-410.

Bligh EG, WJ Dyer.1959. A rapid method of total lipid extraction and purification. Can J Biochem Physiol 37, 911-917.

British Department of Health. 1994. Nutritional aspects of cardiovascular disease. Report on Health and Social Subjects $\mathrm{N}^{\circ} 46$. Her Majesty’s Stationery Office (HMSO), The National Archives, London, UK.

Broderick GA, MK Clayton. 1997. A statistical evaluation of animal and nutritional factors influencing concentrations of milk urea nitrogen. J Dairy Sci 80, 2964-2971.

Butler G, J Nielsen, T Slots, C Seal, M Eyre, R Sanderson, C Leifert. 2008. Fatty acid and fat soluble antioxidant concentrations in milk from high and low input conventional and organic systems: seasonal variation. J Sci Food Agric 88, 1431-1441.

Calvache I. 2009. Variación anual de la concentración de la proteína y grasa láctea en rebaños lecheros del centro y sur de Chile. Tesis de magíster, Facultad de Ciencias Agrarias, Universidad Austral de Chile, Valdivia, Chile.

Collomb M, W Bisig, U Bütikofer. 2008. Seasonal variation in the fatty acid composition of milk supplied to dairies in the mountain regions of Switzerland. Dairy Sci Tech 88, 631-647.

Crumb DJ. 2011. Conjugated Linoleic Acid ( CLA ) - An Overview. Int J Appl Res Nat Prod 4, 12-18.

DeFilippis AP, LS Sperling. 2006. Understanding omega-3's. Am Heart $J$ 151, 564-570.

Dewhurst RJ, ND Scollan, SJ Youell, JKS Tweed, MO Humphreys. 2001. Influence of species, cutting date and cutting interval on the fatty acid composition of grasses. Grass Forage Sci 56, 68-74.

Dhiman TR, GR Anand, LD Satter, MW Pariza. 1999. Conjugated linoleic acid content of milk from cows fed different diets. J Dairy Sci 82, 2146-2156.

Dilzer A, Y Park. 2012. Implication of Conjugated Linoleic Acid (CLA) in Human Health. Crit Rev Food Sci Nutr 52, 488-513.

Elgersma A, G Ellen, $\mathrm{H}$ van der Horst, BG Muuse, H Boer, S Tamminga. 2003. Comparison of the fatty acid composition of fresh and ensiled perennial ryegrass (Lolium perenne L.), affected by cultivar and regrowth interval. Anim Feed Sci Tech 108, 191-205.

Elgersma A, S Tamminga, G Ellen. 2006. Modifying milk composition through forage. Anim Feed Sci Tech 131, 207-225.

Ferlay A, B Martin, P Pradel, J B Coulon, Y Chilliard. 2006. Influence of grass-based diets on milk fatty acid composition and milk lipolytic system in Tarentaise and Montbeliarde cow breeds. J Dairy Sci 89, 4026-4041.

Garnsworthy PC, LL Masson, AL Lock, TT Mottram. 2006. Variation of milk citrate with stage of lactation and de novo fatty acid synthesis in dairy cows. J Dairy Sci 89, 1604-1612.

Goldberg JJ, EE Wildman, JW Pankey, JR Kunkel, DB Howard, MB Murphy. 1992. The influence of intensively managed rotational grazing, traditional continuous grazing, and confinement housing on bulk tank milk quality and udder health. J Dairy Sci 75, 96-104.

Gómez-Cortés P, P Frutos, AR Mantecón, M Juárez, MA de la Fuente, G Hervás. 2009. Effect of supplementation of grazing dairy ewes with a cereal concentrate on animal performance and milk fatty acid profile. J Dairy Sci 92, 3964-3972.

Hartman L, R Lago. 1973. Further observations concerning effects of unsaponifiable constituents on the properties of coffee seed oil. $J$ Am Oil Chem Soc 50, 99-100.

Haug A, AT Høstmark, OM Harstad. 2007. Bovine milk in human nutrition - a review. Lipids Health Dis 6, 25.

Hibbeln JR, TL Blasbalg, JA Riggs, WE Land. 2006. Healthy intakes of $\mathrm{n}-3$ and n-6 fatty acids: estimations considering woldwide diversity. Am J Clin Nutr 83, 1483S-1493S.

Ichihara K, A Shibahara, K Yamamoto, T Nakayama. 1996. An improved method for rapid analysis of the fatty acids of glycerolipids. Lipids 31, 535-539.
Jahreis G, J Pritsche, H Steinhart. 1997. Conjugated linoleic acid in milk fat: High variation depending on production system. Nutr Res 17, 1479-1484.

Jenkins TC, MA McGuire. 2006. Major advances in nutrition: impact on milk composition. J Dairy Sci 89, 1302-1310.

Kalač P, E Samková. 2010. The effects of feeding various forages on fatty acid composition of bovine milk fat: A review. Czech J Anim Sci 55, 521-537.

Kay JK, JR Roche, ES Kolver, NA Thomson, LH Baumgard. 2005. A comparison between feeding systems (pasture and TMR) and the effect of vitamin E supplementation on plasma and milk fatty acid profiles in dairy cows. $J$ Dairy Res 72, 322-332.

Kay JK, WJ Weber, CE Moore, DE Bauman, LB Hansen, H ChesterJones, BA Crooker, LH Baumgard. 2005. Effects of week of lactation and genetic selection for milk yield on milk fatty acid composition in Holstein cows. J Dairy Sci 88, 3886-3893.

Kelly ML, E S Kolver, DE Bauman, ME Van Amburgh, LD Muller. 1998. Effect of intake of pasture on concentrations of conjugated linoleic acid in milk of lactating cows. J Dairy Sci 81, 1630-1636.

Khan NA, TA Tewoldebrhan, RLG Zom, JW Cone, WH Hendriks. 2012. Effect of corn silage harvest maturity and concentrate type on milk fatty acid composition of dairy cows. J Dairy Sci 95, 1472-1483.

Lanuza F. 2011. Suplementos Alimenticios. En: Pulido R, Parga J, Lanuza F, Balocchi O (eds). Suplementación de vacas lecheras a pastoreo. Consorcio Tecnológico de la Leche S.A. Osorno, Chile, Pp 21-48.

Lock AL, DE Bauman. 2004. Modifying milk fat composition of dairy cows to enhance fatty acids beneficial to human health. Lipids 39, 1197-1206.

Lock AL, PC Garnsworthy. 2003. S easonal variation in milk conjugated linoleic acid and D9 -desaturase activity in dairy cows. Livest Prod Sci 79, 47-59.

Lumley ID, RK Colwell. 1991. Extraction of fats from fatty foods and determination of fat content. In: Rossell JB, Pritchard JLR (eds). Analysis of oilseeds, fats and fatty foods. Elsevier Applied Science, London, UK, Pp 227-245.

Morales R, APS Aguiar, I Subiabre, CE Realini. 2013. Beef acceptability and consumer expectations associated with production systems and marbling. Food Qual Prefer 29, 166-173.

Morales-Almaraz E, A Soldado, A González, A Martínez-Fernández, I Domínguez-Vara, B de la Roza-Delgado, F Vicente. 2010. Improving the fatty acid profile of dairy cow milk by combining grazing with feeding of total mixed ration. J Dairy Res 77, 225-230.

Nissen JM, LF Robert. 2009. Efecto del riego, frecuencia de corte y fertilización nitrogenada en una pradera artificial de la región de Los Ríos. Agro Sur 37, 41-51.

ODEPA, Oficina de Estudios y Políticas Agrarias, Chile. 2014. Leche: producción, recepción, precios y comercio exterior, marzo 2014. Santiago, Chile.

Palladino RA, F Buckley, R Prendiville, JJ Murphy, J Callan, DA Kenny. 2010. A comparison between Holstein-Friesian and Jersey dairy cows and their F1 hybrid on milk fatty acid composition under grazing conditions. J Dairy Sci 93, 2176-2184.

Phillips CJC. 2010. Principles of Cattle Production. CABI Publishing, Wallingford Oxon, UK.

Pinto M, E Carrasco, B Fraser, A Letelier, H Walter, P Dörner. 1998. Composición química de la leche cruda y sus variaciones a nivel de silos en plantas lecheras de la VIII, IX y X regiones de Chile. Parte I: Macronutrientes. Agro Sur 26, 97-109.

Pinto M, A Rubilar, E Carrasco, K Shun Ah-Hen, C Brito, L H Molina. 2002. Efecto estacional y del área geográfica en la composición de ácidos grasos en la leche de bovinos. Agro Sur 30, 75-90.

Realini CE, Z Kallas, M Pérez-Juan, I Gómez, JL Olleta, M J Beriain, P Alberti, C Sañudo. 2014. Relative importance of cues underlying Spanish consumers' beef choice and segmentation, and consumer liking of beef enriched with n-3 and CLA fatty acids. Food Qual Prefer 33, 74-85. 
Rego O, P Portugal, M Sousa, H Rosa, C M Vouzela, A Borba, RJB Bessa 2004. Effect of diet on the fatty acid pattern of milk from dairy cows. Anim Res 53, 213-220.

Rico JE, B Moreno, ML Pabón, J Carulla. 2007. Composición de la grasa láctea en la sabana de Bogotá con énfasis en ácido ruménico - CLA cis -9, trans -11. Revista Colombiana de Ciencias Pecuarias 20, 30-39.

Rutkowska J, A Adamska, M Bialek. 2012. Fatty acid profile of the milk of cows reared in the mountain region of Poland. J Dairy Res 79, 469-476.

Ruxton CHS, SC Reed, MJA Simpson, KJ Millington. 2004. The health benefits of omega-3 polyunsaturated fatty acids: a review of the evidence. J Hum Nutr Diet 17, 449-459.

Sadzawka A, M Carrasco, R Demanet, H Flores, R Grez, M L Mora, A Neaman. 2007. Métodos de análisis de tejidos vegetales. Serie Actas - Instituto de Investigaciones Agropecuarias $\mathrm{N}^{\circ}$ 40. Santiago, Chile.

Schnettler B, C Shene, M Rubilar, H Miranda, J Sepúlveda, M Denegri. 2010. Aceptación hacia yogur con diferentes ingredientes funcionales en consumidores de supermercados del sur de Chile. Arch Latinoam Nutr 60, 380-390.

Schnettler B, R Vidal, R Silva, L Vallejos, N Sepúlveda. 2008. Consumer perception of animal welfare and livestock production in the Araucania Region, Chile. Chil J Agr Res 68, 80-93.

Shingfield KJ, L Bernard, C Leroux, Y Chilliard. 2010. Role of trans fatty acids in the nutritional regulation of mammary lipogenesis in ruminants. Animal 4, 1140-1166.

Stoop WM, H Bovenhuis, JML Heck, JAM van Arendonk. 2009. Effect of lactation stage and energy status on milk fat composition of HolsteinFriesian cows. J Dairy Sci 92, 1469-1478.
Thomson N, D Clark, C Waugh, W van der Poel, A MacGibbon. 2000. Effect on milk characteristics to supplementing cows on a restricted pasture allowance with different amounts of either turnips or sorghum. Proceedings of the New Zealand Society of Animal Production 60, 320-323.

Tilley JMA, RA Terry. 1963. A two-stage technique for the in vitro digestion of forage crops. Grass Forage Sci 18, 104-111.

Vanhatalo A, K Kuoppala, V Toivonen, KJ Shingfield. 2007. Effects of forage species and stage of maturity on bovine milk fatty acid composition. Eur J LipidSci Technol 109, 856-867.

Valderrama X, R Anrique. 2011. In situ rumen degradation kinetics of high-protein forage crops in temperate climates. Chil J Agr Res 71, 572-577.

Wallace RJ, R Onodera, MA Cotta. 1997. Metabolism of nitrogencontaining compounds. In: Hobson PN, Stewart CS (eds). The Rumen Microbial Ecosystem. Blackie Academic \& Professional, London, UK, Pp 283-328.

Whigham LD, ME Cook, RL Atkinson. 2000. Conjugated linoleic acid: implications for human health. Pharmacological Research 42, 503-510.

White SL, JA Bertrand, MR Wade, SP Washburn, JT Green, TC Jenkins. 2001. Comparison of fatty acid content of milk from Jersey and Holstein cows consuming pasture or a total mixed ration. J Dairy Sci 84, 2295-2301.

Wyss U, M Collomb, H Frey, P Hofstetter. 2010. Seasonal variation in fatty acid contents of cow milk from indoor and pasture-based feeding. Grassl Sci Eur 15, 634-636. 